\title{
Seasonal changes in antioxidant activity, total phenolic and anthocyanin constituent of the stems of two Morus species (Morus alba L. and Morus nigra L.)
}

\author{
Aysel Sivaci · Münevver Sökmen
}

Published online: 29 January 2008

(C) Springer Science+Business Media B.V. 2008

\section{Erratum to: Plant Growth Regul DOI 10.1007/s10725-004-4500-4}

This erratum corrects errors related with misspelt author's name and formula on page 253 .
1. Author name should be read as Aysel Sivaci.

2. The formula on page 253 should be read as:

$$
I \%=\left(A_{\text {blank }}-A_{\text {sample }} / A_{\text {blank }}\right) \times 100
$$

The online version of the original article can be found under doi:10.1007/s10725-004-4500-4.

\footnotetext{
A. Sivaci

Department of Biology, Sinop Art and Science Faculty, Ondokuz Mayıs University, Sinop, Turkey

M. Sökmen $(\bowtie)$

Department of Chemistry, Art and Science Faculty,

Cumhuriyet University, Sivas, Turkey

e-mail: msokmen@cumhuriyet.edu.tr
} 